\title{
Stability and Temperature-Induced Agglomeration of Rh Nanoparticles Supported by $\mathrm{CeO}_{2}$
}

\author{
Erika Varga, ${ }^{\dagger}$ Péter Pusztai, ${ }^{\dagger}$ Albert Oszkó, ${ }^{\dagger}$ Kornélia Baán, ${ }^{\dagger}$ András Erdőhelyi, ${ }^{\dagger}$ Zoltán Kónya, ${ }^{*},{ }^{\ddagger}, \S$ \\ and János Kiss ${ }^{*}$, ,,$~ P u$
}

${ }^{\dagger}$ Department of Physical Chemistry and Materials Science, ${ }^{\ddagger}$ Department of Applied and Environmental Chemistry, and ${ }^{\S}$ MTA-SZTE Reaction Kinetics and Surface Chemistry Research Group, University of Szeged, H-6720 Szeged, Hungary

Supporting Information

ABSTRACT: The effects of reduction by $\mathrm{H}_{2}$ and by heat treatment in vacuum and in $\mathrm{O}_{2}$ flow on $\mathrm{Rh}$ particle size changes of $\mathrm{Rh} / \mathrm{CeO}_{2}$ samples were studied by X-ray photoelectron spectroscopy (XPS), high-resolution electron microscopy (HRTEM), and CO adsorption followed by diffuse reflectance infrared spectroscopy (DRIFTS). Lowtemperature $(373-423 \mathrm{~K})$ reduction of $\mathrm{Rh}$ without agglomeration is demonstrated. An average particle size of $2.3 \pm 1.1 \mathrm{~nm}$ was measured by HRTEM regardless of the metal loading (1-5\%). On $\mathrm{Rh} / \mathrm{CeO}_{2}$, a significant particle size increase of the $\mathrm{Rh}$ particles was detected on heating $(773 \mathrm{~K})$. In this work, we suggest that the temperature-induced surface decrease resulting from the sintering of $\mathrm{Rh}$ is favored only for well-dispersed particles. XP spectra revealed that the mobile oxygens of $\mathrm{CeO}_{2}$ fundamentally determine the oxidation state of the supported metals. At elevated temperature, the oxidation of the reduced support surface as well as the metal component takes place because of the segregation of ceria oxygens. When the aggregated particles were reoxidized, the redispersion of $\mathrm{Rh}$ was observed probably because of the formation of $\mathrm{Rh}-\mathrm{O}-\mathrm{Ce}$ bonds.

\section{INTRODUCTION}

Highly dispersed metal nanoparticles are attracting increasing amounts of attention in the catalysis and surface science communities as a result of their unusual physical-chemical properties. In heterogeneous catalysis, it is a well-known phenomenon that the state and the structure of a catalyst can be drastically altered during the catalytic reaction, and in many cases, the real catalyst is formed by the effects of the reacting system. Catalysts used in several commercial chemical processes consist of nanoparticles, usually in the $1-10 \mathrm{~nm}$ size range. In many cases, the size and composition of the active site determine the activity of the catalyst and the reaction path. $^{1-6}$ Supported metals such as rhodium may undergo coalescence and various morphological changes during preparation, heat treatment, and reduction. Although in general the pretreatment of the catalysts is carried out at elevated temperature inducing sintering of the noble metal, in most cases this heating procedure is not necessary to obtain fully reduced noble metals. On the other hand, when the support degrades under heating (e.g., titanate nanostructures), ${ }^{7,8}$ lowtemperature pretreatment methods are required. In several lowtemperature reactions including $\mathrm{CO}_{2}$ hydrogenation ${ }^{9,10}$ and certain photoinduced catalytic processes, ${ }^{11,13}$ the particle size plays an important role, so the high-temperature reduction step of the metal oxide, which may lead to sintering, should be avoided. Therefore, the detailed investigation of morphological changes during the reduction and heat treatment is very important in many catalytic systems.

Rhodium supported on $\mathrm{CeO}_{2}$ is a very active catalyst in several reactions. The best catalysts for the simultaneous reduction of $\mathrm{NO}$ and the oxidation of $\mathrm{CO}$ and hydrocarbons contain mainly $\mathrm{Pt}, \mathrm{Pd}$, and $\mathrm{Rh}$ as active components; however, other species, including ceria, are also added to enhance the catalytic performance. ${ }^{14,15}$ It was reported that $\mathrm{Rh} /$ ceria is an excellent water-gas shift catalyst. ${ }^{16,17}$ Furthermore, it was revealed that ceria-supported $\mathrm{Rh}$ was a promising catalyst for carrying out the steam reforming of ethanol ${ }^{18-23}$ and methane. ${ }^{24}$ Until now, in efforts to elucidate how interactions between $\mathrm{CeO}_{2}$ and $\mathrm{Rh}$ affect the catalytic performance, several research groups have used surface science tools to study the reactivity of real and well-defined model systems. ${ }^{15,25-30}$ Recently, it was found that the $\mathrm{Rh}+\mathrm{Co} /$ ceria system was an excellent catalyst for the ethanol steam reforming (ESR) reaction. The addition of a small amount of $\mathrm{Rh}$ as a promoter to the $\mathrm{Co} / \mathrm{CeO}_{2}$ catalyst resulted in a significant further increase in the hydrogen selectivity. ${ }^{21,22}$ At the same time, attention is paid to the oxygen reservoir property of $\mathrm{CeO}_{2}{ }^{31,32}$ Several hypotheses have been put forward, including electron transfer from ceria to $\mathrm{Rh}$ particles, structural variation in the $\mathrm{Rh}$

Received: December 8, 2015

Revised: February 22, 2016 

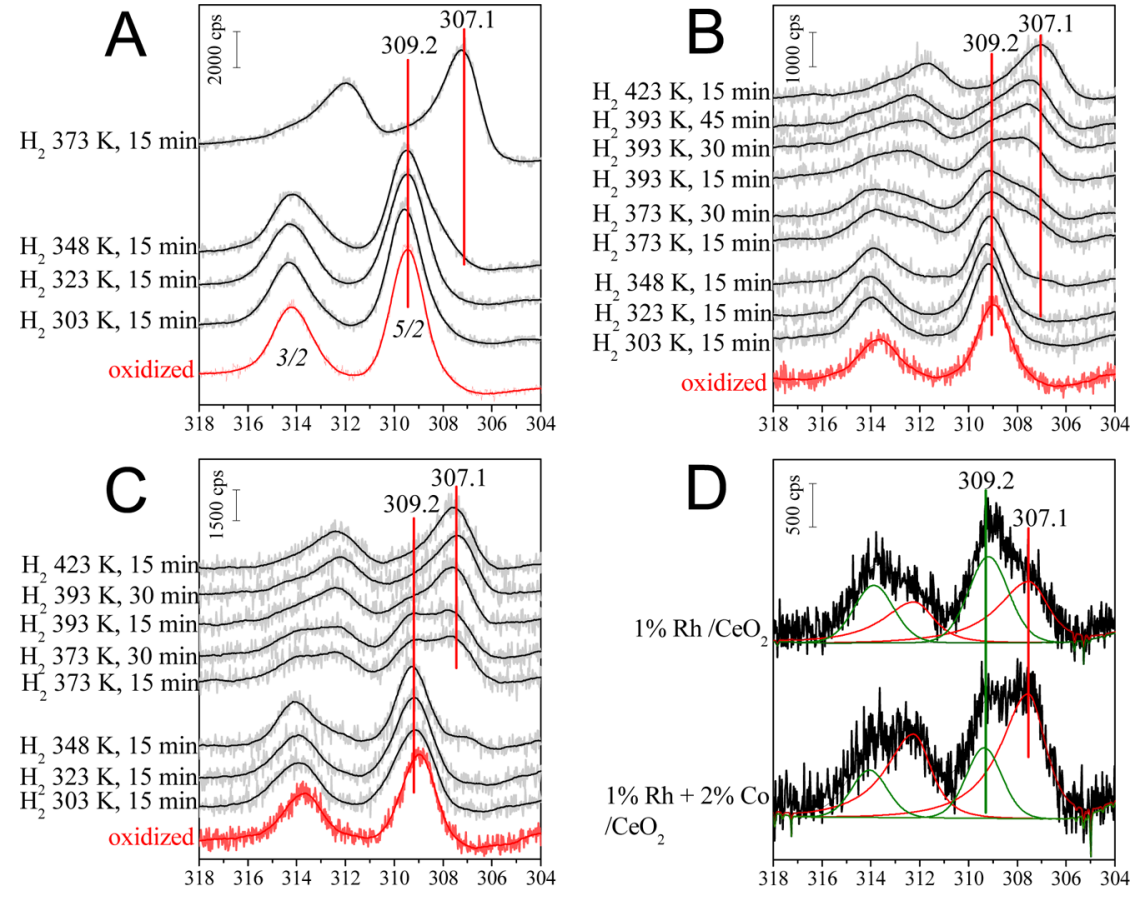

\section{Binding energy $(\mathrm{eV})$}

Figure 1. $\mathrm{Rh} 3 \mathrm{~d}$ spectra during stepwise reduction for $5 \% \mathrm{Rh} / \mathrm{CeO}_{2}(\mathrm{~A}), 1 \% \mathrm{Rh} / \mathrm{CeO}_{2}(\mathrm{~B})$, and $1 \% \mathrm{Rh}+2 \% \mathrm{Co} / \mathrm{CeO}$ (C). (D) Comparative figure of $1 \% \mathrm{Rh} / \mathrm{CeO}_{2}$ with and without $2 \% \mathrm{Co}$, after reduction at $373 \mathrm{~K}$ for $15 \mathrm{~min}$.

particles, and oxygen spillover from $\mathrm{Rh}$ to ceria. $^{28}$ Lowtemperature oxygen migration from ceria to $\mathrm{Rh}$ was also proposed in the ceria-rhodium interaction; in addition, the $\mathrm{Rh}-\mathrm{O}-\mathrm{Ce}$ bond could be formed. ${ }^{15,27,29,30}$ HRTEM images and XP spectra showed significant agglomeration without encapsulation on our $\mathrm{Rh} / \mathrm{CeO}_{2}$ samples, up to $773 \mathrm{~K}^{33}$

In the work presented here, we have focused on the morphological changes of $\mathrm{Rh}$ during the preparation process. The application of impregnated samples instead of model systems makes it possible to obtain Rh species with oxidation states between 0 and +3 . We demonstrate the sintering of reduced $\mathrm{Rh}$ under reduction and heat treatment. In order to avoid the formation of large $\mathrm{Rh}$ particles during reduction, we describe the low-temperature reduction process of $\mathrm{Rh}$. After that, the changes upon subsequent thermal treatment and reoxidation are presented. We also demonstrate the stabilization effect of cobalt ad-species on Rh particle size on the ceria support during heat treatment.

\section{EXPERIMENTAL PROCEDURE}

To acquire information on the effect of the quantity of $\mathrm{Rh}$ and the Co addition, three samples were prepared: $1 \% \mathrm{Rh} / \mathrm{CeO}_{2}, 1 \% \mathrm{Rh}+2 \%$ $\mathrm{Co} / \mathrm{CeO}_{2}$, and $5 \% \mathrm{Rh} / \mathrm{CeO}_{2}$. The catalyst support $\left(\mathrm{CeO}_{2}\right.$, Alfa Aesar, $43 \mathrm{~m}^{2} / \mathrm{g}$ powder) was first calcined at $973 \mathrm{~K}$, then it was impregnated with aqueous solutions of $\mathrm{RhCl}_{3} \cdot 3 \mathrm{H}_{2} \mathrm{O}$ (Johson Matthey) to yield a nominal metal content of 1 or $5 \mathrm{wt} \%$, and finally, the catalysts were dried at $383 \mathrm{~K}$. For the $1 \% \mathrm{Rh}+2 \% \mathrm{Co} / \mathrm{CeO}_{2}$ catalyst, $\mathrm{CeO}_{2}$ was impregnated with an aqueous solution of $\mathrm{Co}\left(\mathrm{NO}_{3}\right)_{2}$ for up to 2 wt \% Co content and was calcined at $973 \mathrm{~K}$. Subsequently, the same sample was impregnated with the $\mathrm{RhCl}_{3} \cdot 3 \mathrm{H}_{2} \mathrm{O}$ solution and was dried at 383 $\mathrm{K}$. The powders were pressed into pellets. Before measurements, they were oxidized at $673 \mathrm{~K}$ in flowing $\mathrm{O}_{2}$ for $20 \mathrm{~min}$.

$\mathrm{XP}$ spectra were taken on a SPECS instrument equipped with a PHOIBOS 150 MCD 9 hemispherical electron energy analyzer using $\mathrm{Al} \mathrm{K} \alpha$ radiation $(h \nu=1486.6 \mathrm{eV})$. The X-ray gun was operated at 210 $\mathrm{W}(14 \mathrm{kV}, 15 \mathrm{~mA})$. The analyzer was operated in FAT mode with the pass energy set to $20 \mathrm{eV}$. For data acquisition and evaluation, the manufacturer's softward (SpecsLab2) and commercial (CasaXPS, Origin) software were used. The binding-energy scale was corrected by fixing the Ce $3 \mathrm{~d} \mathrm{u} \mathrm{u}^{\prime \prime \prime}$ peak to $916.6 \mathrm{eV}$ (Figure S1). ${ }^{34}$ For spectrum deconvolution, the "Curved" named background (supplied by the CasaXPS software), the general Gaussian-Lorentzian (30-70) line shape, and the original asymmetric $\mathrm{Rh} 3 \mathrm{~d}$ line shape were used. The $\mathrm{Ce}^{3+} /\left(\mathrm{Ce}^{3+}+\mathrm{Ce}^{4+}\right)$ ratio was calculated on the basis of Zhang et al. ${ }^{35}$

For XPS studies, the powder samples were pressed into pellets of ca. $1 \mathrm{~cm}$ diameter and a few tenths of a millimeter in thickness. Sample treatments were carried out in a high-pressure cell connected to the analysis chamber via a gate valve. After the different steps of the experiments, the samples were cooled to room temperature in flowing nitrogen. Then, the high-pressure cell was evacuated, and the sample was transferred to the analysis chamber under high vacuum (i.e., without contact with air), where the XP spectra were recorded. As the next step, the sample was moved back into the catalytic chamber, where it was heated to the desired temperature under $\mathrm{N}_{2}$, and then the gas flow was changed to $\mathrm{H}_{2}$ or $\mathrm{O}_{2}$. Nitrogen was not applied in the agglomeration studies.

The same samples were used for XPS measurements throughout the experiments. During the low-temperature reduction, the sample was reduced for $15 \mathrm{~min}$ at the desired temperature that was increased stepwise between two cycles (low-temperature reduction). Agglomeration studies in vacuum were carried out in the $10^{-8}$ mbar pressure range at $773 \mathrm{~K}$ for 1 or $2 \mathrm{~h}$ (heating), followed by oxygen treatment at $673 \mathrm{~K}$ for 30 or $60 \mathrm{~min}$ (reoxidation). In a separate experiment, fresh samples were reduced at $773 \mathrm{~K}$ for $1 \mathrm{~h}$ (high-temperature reduction).

The morphology of ceria and metal-modified ceria was characterized by transmission electron microscopy (FEI Tecnai G 20 XTwin; $200 \mathrm{kV}$ operation voltage, magnification $180000 \times, 125 \mathrm{pm} /$ pixel resolution). The metal particle size distribution was determined using ImageJ software. At least five representative images of equal magnification taken at different spots on the TEM grid were subjected to rolling ball background subtraction and contrast enhancement, and then the diameter of the metal nanoparticles was measured against the calibrated TEM scale bar. Each diameter distribution histogram was constructed from 200 individual nanoparticle diameter measurements. 
DRIFT spectra were recorded using an Agilent CARY-670 FTS-135 FT-IR spectrometer equipped with a diffuse reflectance attachment (Harrick) with $\mathrm{BaF}_{2}$ windows. Typically, 256 scans were registered at a spectral resolution of $2 \mathrm{~cm}^{-1}$. All spectra were recorded at $293 \mathrm{~K}$. The whole optical path was purged with $\mathrm{N}_{2}$ from liquid $\mathrm{N}_{2}$.

\section{RESULTS AND DISCUSSION}

3.1. Low-Temperature Reduction. In our previous work, it was demonstrated that after $1 \mathrm{~h}$ of reduction at $773 \mathrm{~K}$ a significant $\mathrm{Rh} 3 \mathrm{~d}$ intensity decrease was observed by XPS (Figure S2) and was due to the increase in Rh particle size verified by TEM. $^{33}$ At this point, a stepwise temperaturedependent reduction experiment was started to find the lowest temperature for the complete reduction of $\mathrm{Rh}$, which has not yet been done in the literature. Even after oxidation, easily detectable $\mathrm{Cl} 2 \mathrm{p}$ and $2 \mathrm{~s}$ signals contributed to the survey spectra, and the $\mathrm{Rh} 3 \mathrm{~d}$ spectra did not change significantly compared to those of the as-received state (the $5 / 2$ component was located at $309.2 \mathrm{eV}$ ). This indicates that $\mathrm{Rh}$ is in an oxychloride or hydroxychloride form. However, it cannot be excluded that some $\mathrm{Cl}$ migrates to the support, forming $\mathrm{Ce}^{\mathrm{III}}$ oxychloride. $^{36,38}$ By the end of treatments in $\mathrm{H}_{2}$, the residual $\mathrm{Cl}$ was removed.

As depicted in Figure 1A, no reduction took place for 5\% $\mathrm{Rh} / \mathrm{CeO}_{2}$ up to $323 \mathrm{~K}$; however, when the temperature was raised to $348 \mathrm{~K}$, an asymmetric $\mathrm{Rh} 3 \mathrm{~d}$ spectrum could be detected with a shoulder at lower binding energies. After $\mathrm{H}_{2}$ treatment at $373 \mathrm{~K}$ for $15 \mathrm{~min}$, the $\mathrm{Rh}$ content was in the metallic state in full as proven by the binding energy $(307.1 \mathrm{eV}$ for the $5 / 2$ component) and the characteristic line shape of $\mathrm{Rh}^{0}$.

At lower Rh content (1\%), the experiment was longer because after treatment at $348 \mathrm{~K}$ the $\mathrm{Rh} 3 \mathrm{~d}$ spectrum was still very similar to that detected in the oxidized state (Figure 1B). Although significant reduction took place at $373 \mathrm{~K}$ in the first $15 \mathrm{~min}$, no further change could be detected after longer $\mathrm{H}_{2}$ treatment at the same temperature. Upon reduction at $393 \mathrm{~K}$ for 30 or $45 \mathrm{~min}$, almost all of the Rh content became metallic; nevertheless, the temperature was set to $423 \mathrm{~K}$ to make sure that the reduction was complete.

The same experiment was carried out with $1 \% \mathrm{Rh}+2 \% \mathrm{Co} /$ $\mathrm{CeO}_{2}$ (Figure 1C). On the basis of the XPS results, it can be concluded that the presence of a Co additive enhanced the reduction of $\mathrm{Rh}$. Similar to the Co-free case, $373 \mathrm{~K}$ was the lowest temperature for unambiguously starting the reduction. However, it went further on this sample as the $\mathrm{Rh}^{0}$ (\%) peak area increased compared to the total Rh content (it was $73 \%$ instead of 51\%, Figure 1D). TPR results on oxide-supported Rh catalysts generally show the opposite trend, (i.e., the maximum in the $\mathrm{H}_{2}$ consumption is at higher temperature when Co or another transition metal is added ${ }^{39}$ ). This difference in reducibility was explained either by the difference in dispersion $^{40,41}$ or the enrichment of the $\mathrm{Rh}$ surface in the promoters. $^{42,43}$ On the other hand, it can be concluded from the present results that a long duration treatment at a temperature between the threshold temperature and the TPR peak maximum is sufficient only to reduce a certain amount of $\mathrm{Rh}$. To reduce more metal, the temperature must be increased. These observations suggest a stepwise mechanism, which has a significant temperature dependence; however, as shown by this XPS study, the time effect is not negligible either.

No change in the Rh $3 \mathrm{~d}$ peak area occurred up to the total reduction for any of the catalysts; this is one of the conclusions of the XPS experiments. These experimental results indicate that significant agglomeration does not occur during lowtemperature reduction, as also supported by FTIR studies.

The corresponding curves in Figure 2 show the $\mathrm{CO}$ absorption bands over 1 and $5 \% \mathrm{Rh} / \mathrm{CeO}_{2}$ samples after low-

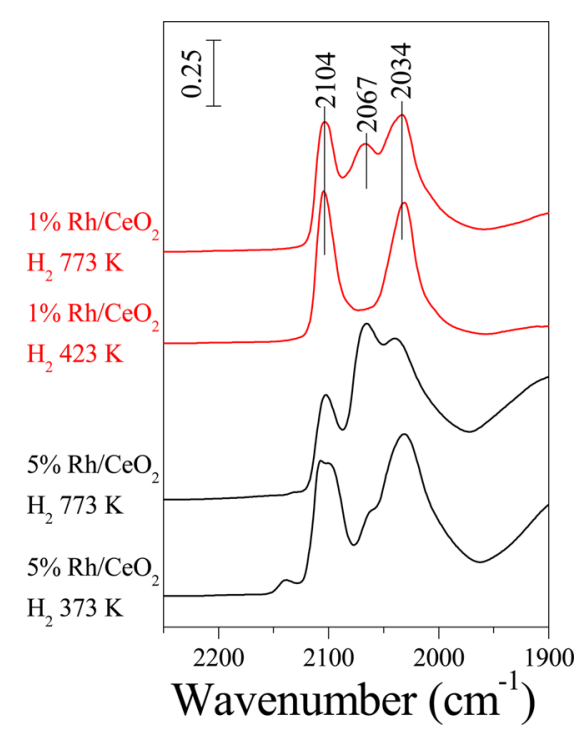

Figure 2. FTIR spectra after $\mathrm{CO}$ adsorption over 1 and $5 \% \mathrm{Rh} / \mathrm{CeO}_{2}$ after low- $(423,373 \mathrm{~K})$ and high-temperature $(773 \mathrm{~K})$ reduction.

temperature reduction. Over the $1 \% \mathrm{Rh} / \mathrm{CeO}_{2}$ sample, the exclusive adsorption of gem-dicarbonyl species (2034 and 2104 $\mathrm{cm}^{-1}$ ) is demonstrated, proving the presence of highly dispersed particles. ${ }^{44,46}$ Over the $5 \% \mathrm{Rh} / \mathrm{CeO}_{2}$ sample, an additional weaker band at $2067 \mathrm{~cm}^{-1}$ also emerged as a result of the linear adsorption mode corresponding to some larger particles, but twin bonding was predominant. The signal at $2140 \mathrm{~cm}^{-1}$ is assigned to a minor number of unreduced $\mathrm{Rh}^{3+}$ ions. ${ }^{47}$ When these samples were reduced at $773 \mathrm{~K}$ for an hour, the proportion of the linearly bonded species increased significantly in both cases as a result of the increased $\mathrm{Rh}$ particle size.

3.2. Temperature-Induced Sintering. After the stepwise reduction experiments, the sintering of metallic $\mathrm{Rh}$ and its reversibility were studied in detail. The samples reduced at 373 or $423 \mathrm{~K}$ were kept at $773 \mathrm{~K}$ under vacuum for 1 and $2 \mathrm{~h}$, respectively, and then the same samples were oxidized at $673 \mathrm{~K}$ for 30 and $60 \mathrm{~min}$. It has been shown that, on heating, $\mathrm{Rh}$ supported on $\mathrm{CeO}_{2}{ }^{28,48}$ or other oxides tends to sinter. ${ }^{5,49,50}$ On heating, a significant XPS intensity decrease was detected for the $1-5 \% \mathrm{Rh} / \mathrm{CeO}_{2}$ samples in the $\mathrm{Rh} 3 \mathrm{~d}$ region (Figure 3A,C, Table 1).

During the experimental work leading to our previous paper, after reduction at $773 \mathrm{~K}$, a significant decrease in the $\mathrm{Rh} 3 \mathrm{~d}$ peak intensity was observed. It was proven by EDX measurement that the $\mathrm{Rh}$ content did not change during this process, and X-ray diffractometry revealed no interaction with $\mathrm{CeO}_{2}$; therefore, sublimation or dissolution into the support cannot be responsible for these changes in XPS intensity.

Transmission electron microscopy revealed that the average particle size was similar on both samples after low-temperature reduction $(2.3 \pm 1.1 \mathrm{~nm})$, thus the particle density must be different on the surface. After heating, the average particle diameter increased to $3.3 \pm 2.0 \mathrm{~nm}$ for $5 \% \mathrm{Rh}$ and $2.5 \pm 0.9 \mathrm{~nm}$ for the $1 \% \mathrm{Rh} / \mathrm{CeO}_{2}$ sample (Figure 4 ). 

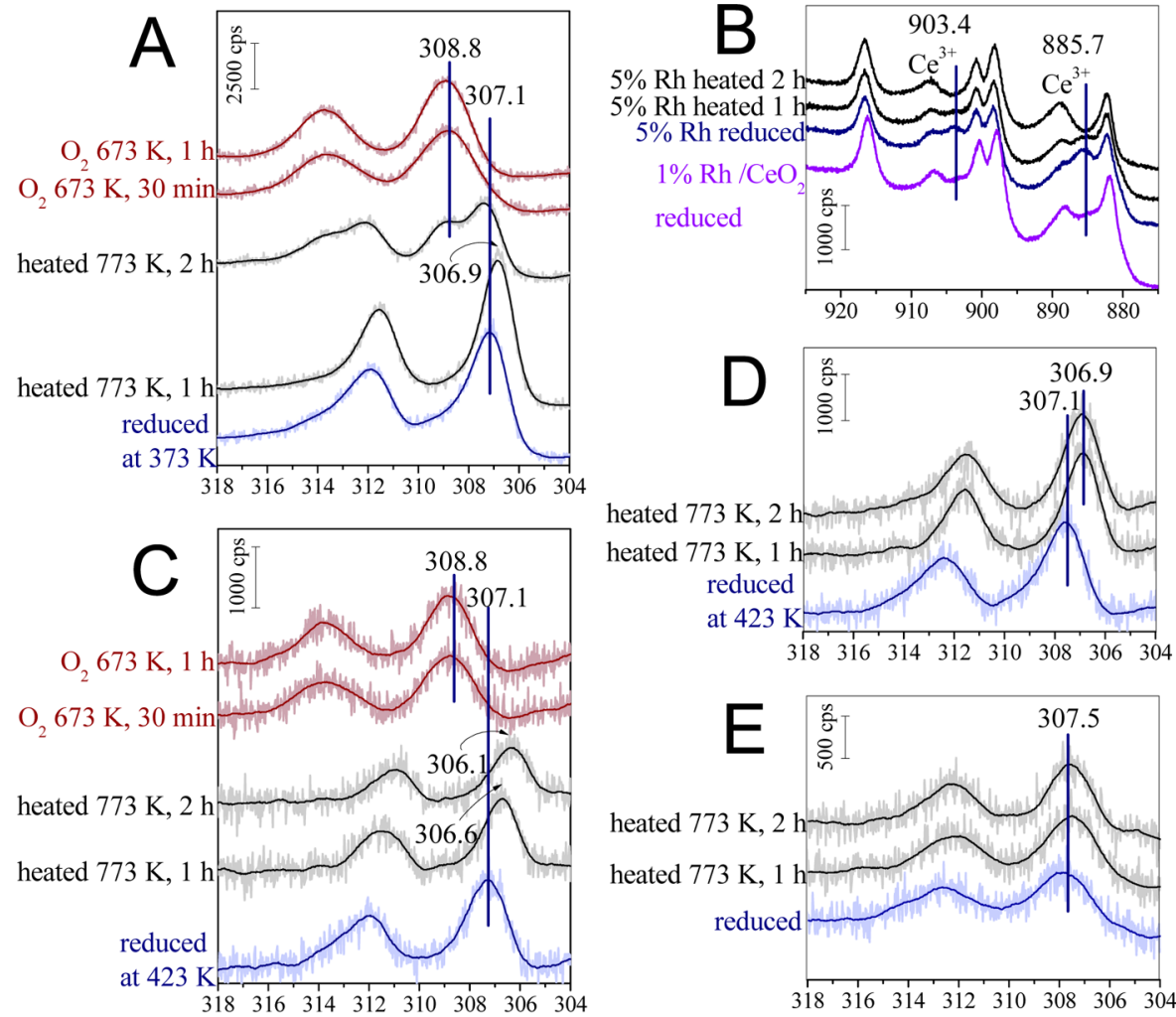

Binding energy $(\mathrm{eV})$

Figure 3. $\mathrm{Rh} 3 \mathrm{~d}$ spectra of $5 \% \mathrm{Rh} / \mathrm{CeO}_{2}(\mathrm{~A}), 1 \% \mathrm{Rh} / \mathrm{CeO}_{2}(\mathrm{C})$, and $1 \% \mathrm{Rh}+2 \% \mathrm{Co} / \mathrm{CeO}_{2}(\mathrm{D})$ after reduction, heating to $773 \mathrm{~K}$ in vacuum, and oxidation at $673 \mathrm{~K}$ as well as $\mathrm{Ce} 3 \mathrm{~d}$ spectra of $5 \% \mathrm{Rh} / \mathrm{CeO}_{2}(\mathrm{~B})$. Comparative results on $1 \% \mathrm{Rh} / \mathrm{Al}_{2} \mathrm{O}_{3}(\mathrm{E})$.

Table 1. Relative Rd 3d Peak Areas (\%) ${ }^{a}$ after Vacuum Agglomeration (after Reduction at Low Temperature) and Consecutive Reoxidation Experiments ${ }^{b}$

$\begin{array}{ccrrcc} & \text { reduced in } & \text { in vacuo } & \text { in vacuo } & \mathrm{O}_{2} 673 \mathrm{~K} & \mathrm{O}_{2} 673 \\ \text { sample } & \mathrm{H}_{2} \text { at } 773 \mathrm{~K} & 773 \mathrm{~K} \mathrm{1h} & 773 \mathrm{~K} 2 \mathrm{~h} & 30 \mathrm{~min} & \mathrm{~K} 1 \mathrm{~h} \\ 5 \% \mathrm{Rh} / \mathrm{CeO}_{2} & 72 & 90 & 70 & 75 & 81 \\ 1 \% \mathrm{Rh} / \mathrm{CeO}_{2} & 48 & 61 & 48 & 63 & 74 \\ 1 \% \mathrm{Rh}+2 \% & 45 & \sim 100 & \sim 100 & & \end{array}$

$\mathrm{Co} / \mathrm{CeO}_{2}$

${ }^{a}$ Peak areas were referenced to the peaks obtained after lowtemperature reduction: $15 \mathrm{~min}$ in $\mathrm{H}_{2}$ at $673 \mathrm{~K}$ for $5 \% \mathrm{Rh} / \mathrm{CeO}_{2}$ and $15 \mathrm{~min}$ in $\mathrm{H}_{2}$ at $423 \mathrm{~K}$ for $1 \% \mathrm{Rh} / \mathrm{CeO}_{2}$ and $1 \% \mathrm{Rh}+2 \% \mathrm{Co} /$ $\mathrm{CeO}_{2} .{ }^{b}$ Comparative results on high-temperature reduction (separate experiment) are in the first column.

In contrast, the relative XPS peak area changes included in Table 1 suggest a larger alteration for the $1 \% \mathrm{Rh} / \mathrm{CeO}_{2}$ sample than for the one with $5 \% \mathrm{Rh}$. Because a wide range of $\mathrm{Rh}$ particle sizes were measured on the samples, it is worth paying attention to the particle size distributions (Figure 5). Here, it can be seen clearly that at high $\mathrm{Rh}$ content the sample became more heterogeneous: new, larger particles appeared, while for the $1 \% \mathrm{Rh} / \mathrm{CeO}_{2}$ sample, the ratio of the smaller particles only decreased. This difference is attributed to the different particle numbers and the statistical growth of $\mathrm{Rh}$. The coalescence of the very small metal particles could be the first step, which induces a more significant alteration in the surface area and intensity loss in XPS.

Not only the particle size increase but also, for reducible oxides such as $\mathrm{CeO}_{2}$, the decoration effect can reduce the available surface. ${ }^{51,52}$ Here, this phenomenon plays only a minor role because no intensity change in the $\mathrm{CO}$ vibrational region was detected even after high-temperature $(773 \mathrm{~K})$ reduction (Figure 2), similar to what was found by Bernal et al. $^{53}$ and in line with former results proving that decoration occurs only on $\mathrm{Rh} / \mathrm{CeO}_{2}$ reduced at temperature higher than $773 \mathrm{~K}^{53-55}$

Another interesting phenomenon is that the $\mathrm{Rh} 3 \mathrm{~d}$ peak maximum shifted to lower values after heating at every $\mathrm{Rh}$ content. No relationship could be detected among the $\mathrm{Rh} 3 \mathrm{~d}$, $\mathrm{Ce} 3 \mathrm{~d}$, and $\mathrm{O} 1 \mathrm{~s}$ spectra, which would unambiguously indicate bonding type changes. Unfortunately, this shift can be detected only for samples that had been stored under high vacuum, which makes a structural study by TEM impossible in our systems. However, for Au particles, some papers have already been published dealing with the separation of the initial and the final state effects in XPS. It was reported that the more spherical the particles are, the lower the average coordination number on the surface is, and the more dominant initial state effect causes the binding energy shift to lower values. ${ }^{56,57}$ In studies concerning $\mathrm{Rh}$ oxides, negative $\mathrm{Rh} 3 \mathrm{~d}$ binding energy shifts were also ascribed to the metal-metal oxide interface. ${ }^{58,59}$ Because at this stage of experiment no Rh oxide was detected by XPS, a more relevant explanation could be the strong electronic interaction between the support and the supported metal playing an important role in heterogeneous catalysis. ${ }^{8,60,61}$ Sevcikova et al. also found a negative shift in the $\mathrm{Rh} 3 \mathrm{~d}$ spectra of $\mathrm{Rh}$ supported on reduced $\mathrm{CeO}_{2}$, having been attributed to the net negative charge on $\mathrm{Rh}$ resulting from $\mathrm{Ce}-$ $\mathrm{Rh}$ charge transfer. ${ }^{62}$ The contribution of this effect is also possible in this case. 

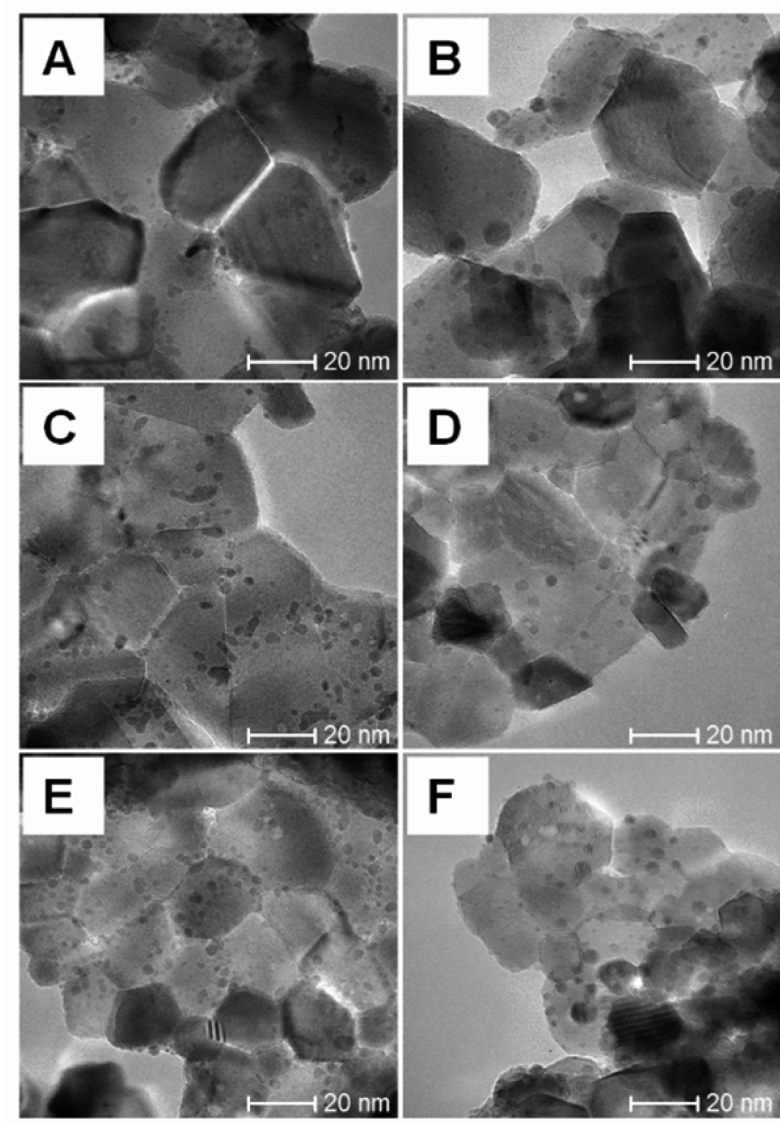

Figure 4. TEM images of $5 \% \mathrm{Rh} / \mathrm{CeO}_{2},(\mathrm{~A}, \mathrm{~B}) 1 \% \mathrm{Rh} / \mathrm{CeO}_{2}$ (C, D), and $2 \% \mathrm{Co}+1 \% \mathrm{Rh} / \mathrm{CeO}_{2}(\mathrm{E}, \mathrm{F})$ after low-temperature reduction and heat treatment, respectively. $\mathrm{Rh}$ particles appear as small, round dark spots on the significantly larger $\mathrm{CeO}_{2}$ particles; $\mathrm{Co}$ is not discernible in panels $\mathrm{E}$ and $\mathrm{F}$.

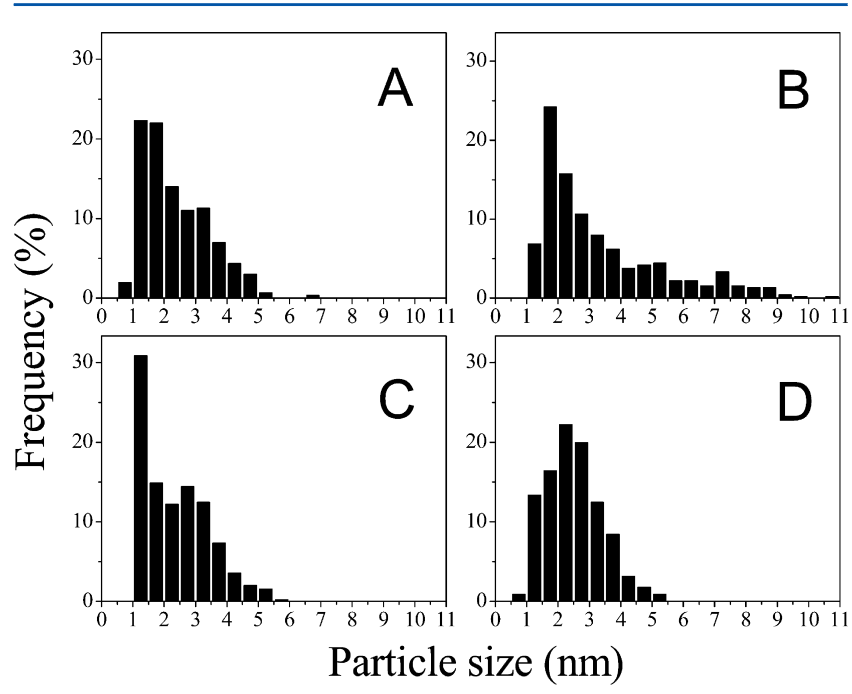

Figure 5. $\mathrm{Rh}$ particle size distributions of $5 \% \mathrm{Rh} / \mathrm{CeO}_{2}$ after reduction (A) and $2 \mathrm{~h}$ of heating (B) and $1 \% \mathrm{Rh} / \mathrm{CeO}_{2}$ after reduction (C) and heating (D).

For $1 \% \mathrm{Rh} / \mathrm{CeO}_{2}$, trends similar to those for $5 \% \mathrm{Rh}$ can be observed; however, the effects of both the agglomeration and redisruption were enhanced (Figure 3C, Table 1).

Bernal et al. $^{54}$ in their extended reduction and reoxidation HREM studies with $\mathrm{Rh}$ supported on low-surface-area $\mathrm{CeO}_{2}$ $\left(11 \mathrm{~m}^{2} / \mathrm{g}\right)$ reported similar observations that are included in the present work but in different temperature regimes. The $\mathrm{Rh}$ particle size started to increase at the $973 \mathrm{~K}$ reduction temperature, and this effect was significant at $1173 \mathrm{~K}$. In addition, decoration by $\mathrm{CeO}_{2}$ was observed over these two samples. Reoxidation up to $773 \mathrm{~K}$ did not result in changes in the $\mathrm{Rh}$ particle size; however, treatment at $1173 \mathrm{~K}$ induced smaller metal particles. This comparison points out the importance of the different experimental details (e.g., surface area and preparation methods); nevertheless, the general behavior of the systems is analogous.

Concerning $\mathrm{Pd} / \mathrm{Ce}_{0.5} \mathrm{Zr}_{0.5} \mathrm{O}_{2}$ catalysts, it was shown that the heat treatment in $\mathrm{H}_{2}$ or $\mathrm{N}_{2}$ induced the agglomeration of the precious metal; however, in the presence of $\mathrm{O}_{2}$, this effect was hindered. When $\mathrm{Pd}$ was supported on $\mathrm{Al}_{2} \mathrm{O}_{3}$, a severe increase in particle size took place regardless of the aging atmosphere. ${ }^{63}$ After calcination, the $\mathrm{Pd} / \mathrm{Ce}_{0.5} \mathrm{Zr}_{0.5} \mathrm{O}_{2}$ samples were treated with $\mathrm{O}_{2}$-containing gas, and the redispersion of $\mathrm{Pd}$ particles was detected, which has a significant dependence on the cooling rate. ${ }^{64}$ All of these observation were attributed to the probable formation of a $\mathrm{Pd}-\mathrm{O}-\mathrm{Ce}$ bond anchoring the $\mathrm{Pd}$ particles and inhibiting agglomeration. Similar effects were proposed for $\mathrm{Au}$ and $\mathrm{Pt}^{65-67}$ As far as $\mathrm{Rh}$ is concerned, the presence of $\mathrm{Rh}-\mathrm{O}-$ $\mathrm{Ce}$ bonding was detected in $\mathrm{Rh} / \mathrm{CeO}_{2} / \mathrm{SiO}_{2}$ and $\mathrm{Rh} / \mathrm{CeO}_{2}$ samples by EXAFS. ${ }^{30,68}$

Dictor et al. reported similar results on a $\mathrm{CeO}_{2}$-doped $\mathrm{Rh} /$ $\mathrm{Al}_{2} \mathrm{O}_{3}$ sample. ${ }^{69}$ In their work, FTIR spectroscopy was applied to characterize the morphology of $\mathrm{Rh}$, while prolonged heating was applied to $\mathrm{CO}$ or $\mathrm{H}_{2}$, resulting in the diminishing of dicarbonyl bands, indicating the agglomeration of Rh. After $\mathrm{O}_{2}$ pulses at $673 \mathrm{~K}$, the redispersion of the metal was observed. It was stated that the $\mathrm{CeO}_{2}$-promoted sample was more resistant toward agglomeration than the unpromoted one. Nevertheless, in our separate experiment with $1 \% \mathrm{Rh} / \mathrm{Al}_{2} \mathrm{O}_{3}$, no $\mathrm{Rh} 3 \mathrm{~d}$ intensity decrease took place after reduction (Figure $3 \mathrm{E}$ ); however, in the reduced state, the total peak area was only half of the value at $1 \% \mathrm{Rh} / \mathrm{CeO}_{2}$ (Figure 3C), suggesting larger particles. It is assumed that above a specified particle distribution sintering is not favored.

To underline the previous statement, comparative results are depicted in Figure $\mathrm{S} 2$ on $1 \% \mathrm{Rh} / \mathrm{CeO}_{2}$ reduced at low or high temperatures. When reduced at $773 \mathrm{~K}$ (separate experiment), $\mathrm{Rh}$ gave a dramatically lower $3 \mathrm{~d}$ peak intensity than after lowtemperature reduction, predicting larger particle sizes resulting from the double effect of heat treatment and reducing conditions (Table 1, Figure S2). Similar results were obtained for the $5 \% \mathrm{Rh} / \mathrm{CeO}_{2}$ sample. However, when $1 \% \mathrm{Rh} / \mathrm{CeO}_{2}$ was linearly heated to $773 \mathrm{~K}$ in $\mathrm{N}_{2}$ after high-temperature reduction, only one new component was detected at $308.8 \mathrm{eV}$ as a result of oxygen spillover to $\mathrm{Rh}$ without any additional peak area changes. Here, it is intended to show that when extremely sintered $\mathrm{Rh}$ particles are heated under an inert atmosphere, additional aggregation hardly takes place. On the other hand, the oxygen spillover from $\mathrm{CeO}_{2}$ is not enough to fully oxidize and disrupt the particles.

The addition of $2 \%$ Co changed the behavior of the sample completely; after heating, only a minor peak shift was observed without a decrease in the Rh $3 \mathrm{~d}$ peak area (Figure 3D). Most particles had a diameter of between 1 and $1.5 \mathrm{~nm}$ (Figure 4), thus it can be concluded that Co inhibits the formation of large $\mathrm{Rh}$ particles. In the literature, the enrichment of the transition metal on the noble metal surface is also suggested. ${ }^{70,71}$ This could have an effect on the coalescence of $\mathrm{Rh}$ particles as well 
as the alloy formation between $\mathrm{Co}$ and high $\mathrm{Rh}$ content. A behavior like this was identified for $\mathrm{Rh} / \mathrm{MgO}$ by EXAFS and FTIR CO adsorption studies. ${ }^{71-73}$

In our case, the total amount of Co is still in the oxidized state after the low-temperature reduction; therefore, alloy formation is not likely. In addition, referring to our previous results in which a wide range of $\mathrm{Co}-\mathrm{Rh}$ samples with different $\mathrm{Co}-\mathrm{Rh}$ contents were studied, the $\mathrm{Rh} 3 \mathrm{~d}$ and Co $2 \mathrm{p}$ binding energies did not shift in the bimetallic samples compared to in the monometallic ones. ${ }^{33}$ DRIFT spectra could not prove the formation of bimetallic particles either. Co dissolved into the support so strongly, as proven by the combination of XPS and low-energy ion scattering spectroscopy (LEIS), that it could not been studied by either XRD or TEM. On the basis of the lack of the strong electronic interaction and the similarity of the $\mathrm{Rh}$ particle sizes on $1 \% \mathrm{Rh} / \mathrm{CeO}_{2}$ and $1 \% \mathrm{Rh}+2 \% \mathrm{Co} / \mathrm{CeO}_{2}$, we suggest that $\mathrm{Rh}$ and the well-dispersed Co species (mainly $\mathrm{Co}^{2+}$ ) form separate phases. These objects must be close to each other because hydrogen spillover can take place. Co could inhibit the sintering of $\mathrm{Rh}$ by blocking its migration.

In Table 1 it is demonstrated that on heating in $\mathrm{H}_{2}$, a comparable peak area decrease occurred over the $1 \% \mathrm{Rh}+2 \%$ / $\mathrm{CeO}_{2}$ sample comparable to that after $2 \mathrm{~h}$ of heating in vacuum over the $1 \% \mathrm{Rh} / \mathrm{CeO}_{2}$ sample, indicating the importance of the atmosphere. The dispersing effect of Co on $\mathrm{Rh}$ is still valid because the starting Rh $3 \mathrm{~d}$ peak area is significant larger in the presence of $\mathrm{Co}$, thus smaller particles must be considered at the beginning and, consequently, after sintering.

3.3. Effect of the $\mathrm{CeO}_{2}$ Oxygens and the Reoxidation of Rhodium. In addition to the former observations concerning temperature-induced agglomeration, the partial oxidation of $\mathrm{Rh}$ at $5 \%$ during $2 \mathrm{~h}$ of heating was also detected. Taking into account the previous results with similar samples, this can be related to the enhanced $\mathrm{O}$ mobility of $\mathrm{CeO}_{2}$ at high temperature. ${ }^{33}$ The addition of more $\mathrm{Rh}$ resulted in a more intense reduction of $\mathrm{CeO}_{2}$ (the $\mathrm{Ce}^{3+} /\left(\mathrm{Ce}^{3+}+\mathrm{Ce}^{4+}\right)$ ratio was $27 \%$ compared to $23 \%$ at $1 \% \mathrm{Rh}$, Figure S1), causing a steeper $\mathrm{O}$ gradient, which can enhance the segregation of $\mathrm{O}$ (Figure $3 \mathrm{~B})$. By the end of the $2 \mathrm{~h}$ long heating, the $\mathrm{Ce}^{3+}$ content decreased to $10 \%$, similar to the value obtained after oxidation. A similar trend was observed over $1 \% \mathrm{Rh} / \mathrm{CeO}_{2}$ and $1 \% \mathrm{Rh}+$ $2 \% \mathrm{Co} / \mathrm{CeO}_{2}$ but with much smaller spectral changes. On the other hand, the various reduction state of a reducible oxide can also influence the agglomeration process because $O$ vacancies of the oxide support stabilize the dispersed state ${ }^{74-77}$ However, the effect here is controversial because, according to some theoretical work, $\mathrm{Rh}$ does not tend to sit inside the vacancies; ${ }^{78}$ moreover, subsurface vacancies are more stable than the ones in the topmost layer. ${ }^{79}$

In some work, enhanced $\mathrm{O}$-storage capacity by supercharging (presence of surface superoxide ions $\left(\mathrm{O}_{2}^{-}\right)$) on the surface was concluded for small $\mathrm{CeO}_{2}$ particles, ${ }^{80-82}$ while the photocatalytic activity of ceria was attributed to the formation of superoxide radicals. ${ }^{83,84}$ Significant changes in the $\mathrm{O} 1 \mathrm{~s}$ region was observed only for high $\mathrm{Rh}$ content (Figure 6). The main peak centered at $529.3 \mathrm{eV}$ is unambiguously identified as ceria lattice oxygen. Because the intensity of the smaller component at $531.2 \mathrm{eV}$ was similar after oxidation and reduction, it is attributed to the presence of surface $-\mathrm{OH}$ groups rather than to vacancy-related species. ${ }^{82,85,86}$ Water $(533.1 \mathrm{eV})$ was removed by heat treatment, and a new component emerged at $530.2 \mathrm{eV}$. Comparing it with our $\mathrm{Rh} 3 \mathrm{~d}$ results, in which after $2 \mathrm{~h}$ of heating part of the $\mathrm{Rh}$ was oxidized and after oxidation

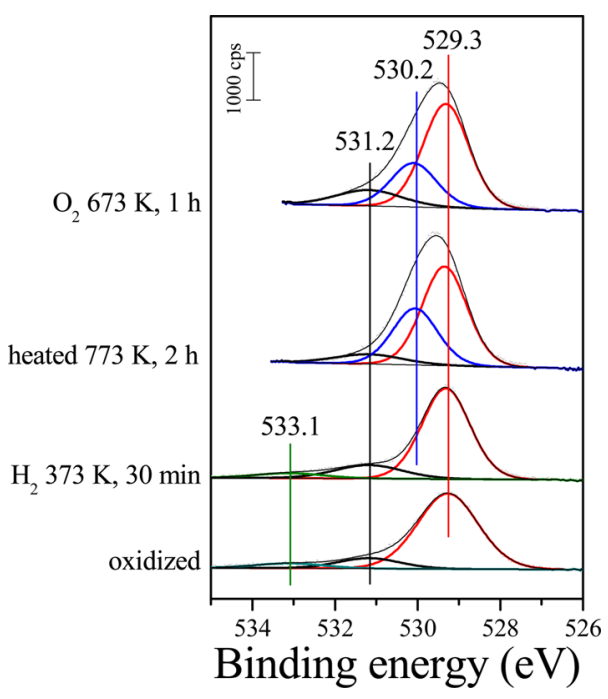

Figure 6. $\mathrm{O}$ 1s spectra of $5 \% \mathrm{Rh} / \mathrm{CeO}_{2}$ after oxidization, total reduction, heating, and reoxidation.

$\mathrm{Rh}$ was in the oxidized state completely, we ascribe it to metalbonded $\mathrm{O}$ and $\mathrm{OH}$ species on the surface of the $\mathrm{Rh}$ particles. ${ }^{87,88}$ The intensity discrepancy can be due to the different stoichiometry. After $2 \mathrm{~h}$ of heating, oxygen was deposited on top of the $\mathrm{Rh}$ particles, but during oxidation, $\mathrm{Rh}_{2} \mathrm{O}_{3}$ formation took place. Similar reverse $\mathrm{O}$-spillover from $\mathrm{CeO}_{2}$ to Pt was demonstrated by Vayssilov et al. ${ }^{89}$ as well as by Zafiris et al. for $\mathrm{Rh} / \mathrm{CeO}_{2}{ }^{15} \mathrm{On} \mathrm{Pt} / \mathrm{CeO}_{x} / \mathrm{TiO}_{2}(110)$, Bruix et al. obtained the same effect. ${ }^{90} \mathrm{Lin}$ et al. demonstrated by ${ }^{18} \mathrm{O}$ labeling that the oxygen in reoxidized $\mathrm{PtO}_{x}$ definitely originated from the ceria lattice instead of the $\mathrm{O}_{2}$ reagent. They also emphasized the role of the surface $\mathrm{OH}$ group in the stabilization of dispersed particles. ${ }^{67}$

When reoxidized in $\mathrm{O}_{2}$ flow after agglomeration, in the 1$5 \% \mathrm{Rh} / \mathrm{CeO}_{2}$ samples, the $\mathrm{Rh} 3 \mathrm{~d}_{5 / 2}$ peak was located at 308.8 $\mathrm{eV}$ with a larger fwhm than after oxidation pretreatment at the beginning (Figures $1 \mathrm{~A}, \mathrm{~B}$ and $3 \mathrm{~A}, \mathrm{C}$ ). It is attributed to the formation of $\mathrm{Rh}_{2} \mathrm{O}_{3}$; nevertheless, the contribution of $\mathrm{Rh}$ oxides with other stoichiometry cannot be excluded. ${ }^{58,91,92}$ In Figure $3 \mathrm{~A}, \mathrm{C}$ and Table 1, it is well demonstrated that the peak area also increased stepwise under oxidation. According to TEM measurements, most Rh particles had diameters in the 1$1.5 \mathrm{~nm}$ region.

As an additional experiment, we probed the temperatureinduced agglomeration on the oxidized $1 \% \mathrm{Rh} / \mathrm{CeO}_{2}$ sample and summarized the results in Figure 7. The supported metal was fully reduced after the first hour of heating, and similar $\mathrm{Rh}$ $3 \mathrm{~d}$ peak area changes were obtained to that found on the reduced sample. On the other hand, $\mathrm{CeO}_{2}$ exhibited opposite behavior compared to the previous observations in this work, and it was slightly reduced under heating. The increased number of $\mathrm{O}$ vacancies in $\mathrm{CeO}_{2}$ on heating has been frequently presented. ${ }^{85,93}$ Considering that on the as-received sample and on the metal-free $\mathrm{CeO}_{2}$ no changes took place (not shown), the release of $\mathrm{O}_{2}$ molecules is assumed, which is catalyzed by $\mathrm{Rh}$. Experimental and theoretical studies verify that the addition of noble metals enhances the reduction of $\mathrm{CeO}_{2}$ as a result of the appearance of metal-induced gap states, which offer the opportunity to accommodate extra electrons. ${ }^{94-96}$ 


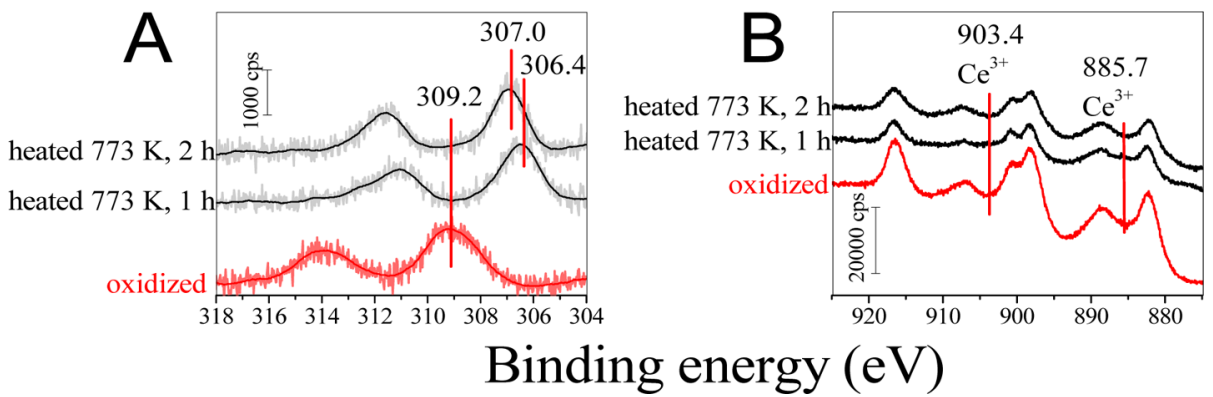

Figure 7. $\mathrm{Rh} 3 \mathrm{~d}(\mathrm{~A})$ and $\mathrm{Ce} 3 \mathrm{~d}(\mathrm{~B})$ spectra of $1 \% \mathrm{Rh} / \mathrm{CeO}_{2}$ after oxidation and subsequent heating in vacuum.

\section{SUMMARY AND CONCLUSIONS}

The effects of metal loading and the Co additive on the temperature-induced agglomeration of $\mathrm{Rh}$ were studied in $\mathrm{Rh} /$ $\mathrm{CeO}_{2}$ and $\mathrm{Rh}+\mathrm{Co} / \mathrm{CeO}_{2}$ samples. Our conclusions are summarized as follows.

(1) XPS revealed that Rh supported on $\mathrm{CeO}_{2}$ can be reduced at low temperature (at $373 \mathrm{~K}$ for $5 \% \mathrm{Rh}$ and $423 \mathrm{~K}$ for $1 \% \mathrm{Rh}$ content). The $\mathrm{Rh} 3 \mathrm{~d}$ peak areas did not change until complete reduction. Carbon monoxide was adsorbed as gem-dicarbonyls over $1 \% \mathrm{Rh}$, and over $5 \% \mathrm{Rh}$, it was predominant as well. Thus, it was concluded that the $\mathrm{Rh}$ content can be reduced in the $373-423 \mathrm{~K}$ temperature range without the aggregation of the metal particles. TEM investigations proved that the average particle size was similar at $1-5 \%$ Rh loadings $(\sim 2.3 \mathrm{~nm})$; however, the particle size distribution is heterogeneous.

(2) On the basis of the Rh $3 \mathrm{~d}$ intensity decrease and TEM measurements a particle size increase was detected over the $\mathrm{Rh} / \mathrm{CeO}_{2}$ samples after heating in vacuum. From comparative studies with $\mathrm{Rh} / \mathrm{Al}_{2} \mathrm{O}_{3}$ and $\mathrm{Rh} / \mathrm{CeO}_{2}$ reduced at $773 \mathrm{~K}$, we suggest that at a given particle size distribution the agglomeration process is no longer favore. Because no intensity decrease took place in the CO vibration region in our DRIFT experiment, we attribute only a minor role to the encapsulation of $\mathrm{Rh}$ by $\mathrm{CeO}_{2}$. The addition of $\mathrm{Co}$ prohibited the sintering process when the sample was heated in vacuum.

(3) The oxygen treatments at elevated temperature $(673 \mathrm{~K})$ were able to redisperse the aggregated $\mathrm{Rh}$ particles, probably because of the formation of $\mathrm{Ce}-\mathrm{O}-\mathrm{Rh}$ bonds.

(4) XP spectra revealed that the mobile oxygens of $\mathrm{CeO}_{2}$ fundamentally determine the oxidation state of the supported metals. At elevated temperature, the oxidation of the reduced support surface and the metals takes place because of the segregation of oxygen species originating from ceria at the surface. On the other hand, the oxidized $\mathrm{CeO}_{2}$ surface can release oxygen easily in the presence of $\mathrm{Rh}$ accompanied by the reduction of the noble metal.

\section{ASSOCIATED CONTENT}

\section{S Supporting Information}

The Supporting Information is available free of charge on the ACS Publications website at DOI: 10.1021/acs.langmuir.5b04482.

Deconvoluted Ce 3d spectrum of $5 \% \mathrm{Rh} / \mathrm{CeO}_{2}$ after low-temperature reduction and $\mathrm{Rh} 3 \mathrm{~d}$ spectra of $1 \% \mathrm{Rh} /$ $\mathrm{CeO}_{2}$ (PDF)

\section{AUTHOR INFORMATION}

\section{Corresponding Author}

*E-mail: jkiss@chem.u-szeged.hu.

\section{Notes}

The authors declare no competing financial interest.

\section{ACKNOWLEDGMENTS}

This work was supported by the Alexander von Humboldt Foundation within the Research Group Linkage Program.

\section{REFERENCES}

(1) Musselwhite, N.; Somorjai, G. A. Investigations of structure sensitivity in heterogeneous catalysis: From single crystals to monodisperse nanoparticles. Top. Catal. 2013, 56, 1277-1283.

(2) Freund, H.-J.; Nilius, N.; Risse, T.; Schauerman, S. A fresh look at an old nanotechnology: catalysis. Phys. Chem. Chem. Phys. 2014, 16, $8148-8167$

(3) Goodman, D. W. Chemistry: Precious little catalyst. Nature 2008, 454, 948-949.

(4) Park, J. Y.; Zhang, Y.; Grass, M.; Zhang, T.; Somorjai, G. A. Tuning of catalytic $\mathrm{CO}$ oxidation by changing composition of Rh-Pt nanoparticles. Nano Lett. 2008, 8, 673-677.

(5) Berkó, A.; Solymosi, F. Adsoption-induced structural changes of $\mathrm{Rh}$ supported by $\mathrm{TiO}_{2}(110)-(1 \times 2)$ : An STM study. J. Catal. 1999, 183, 91-101.

(6) Frank, M.; Kühnemuth, R.; Bäumer, M.; Freund, H.-J. Oxidesupported Rh particle structure probed with carbon monoxide. Surf. Sci. 1999, 427-428, 288-293.

(7) Morgado, E., Jr.; de Abreu, M. A. S.; Moure, G. T.; Marinkovic, B. A.; Jardim, P. M.; Araujo, A. S. Effects of thermal treatment of nanostructured trititanates on their chrystallographic and textural properties. Mater. Res. Bull. 2007, 42, 1748-1760.

(8) Pótári, G.; Madarász, D.; Nagy, L.; László, B.; Sápi, A.; Oszkó, A.; Kukovecz, Á.; Erdőhelyi, A.; Kónya, Z.; Kiss, J. Rh-induced support transformation phenomena in titanate nanowire and nanotube catalysts. Langmuir 2013, 29, 3061-3072.

(9) Iizuka, T.; Tanaka, Y.; Tanabe, K. Hydrogenation of $\mathrm{CO}$ and $\mathrm{CO}_{2}$ over rhodium catalysts supported on various metal oxides. J. Catal. 1982, 76, 1-8.

(10) Karelovic, A.; Ruiz, P. $\mathrm{CO}_{2}$ hydrogenation at low temperature over $\mathrm{Rh} / \gamma-\mathrm{Al}_{2} \mathrm{O}_{3}$ catalysts: Effect of the noble metal particle size on catalytic performances and reaction mechanism. Appl. Catal., B 2012, 113-114, 237-249.

(11) Henderson, M. A. A surface science perspective in $\mathrm{TiO}_{2}$ photocatalysis. Surf. Sci. Rep. 2011, 66, 185-297.

(12) Watson, A. M.; Zhang, X.; de la Osa, R. A.; Sanz, J. M.; González, F.; Moreno, F.; Finkelstein, G.; Liu, J.; Everitt, H. O. Rhodium nanoparticles for ultraviolet plasmonics. Nano Lett. 2015, 15, $1095-1100$

(13) Ola, O.; Maroto-Valer, M. M. Review of material design and reactor engineering on $\mathrm{TiO}_{2}$ photocatalysis for $\mathrm{CO}_{2}$ reduction. J. Photochem. Photobiol., C 2015, 24, 16-42.

(14) Yao, H. C.; Yu Yao, Y. C. Ceria in automotive exhaust catalysts. I. Oxygen storage. J. Catal. 1984, 86, 254-265.

(15) Zafiris, G. S.; Gorte, R. J. Evidence for low-temperature oxygen migration from ceria to Rh. J. Catal. 1993, 139, 561-567. 
(16) Schlatter, J. C.; Mitchell, P. J. Three-way catalyst response to transients. Ind. Eng. Chem. Prod. Res. Dev. 1980, 19, 288-293.

(17) Kim, G. Ceria-promoted three-way catalysts for auto exhaust emission control. Ind. Eng. Chem. Prod. Res. Dev. 1982, 21, 267-274.

(18) da Silva, A. M.; de Souza, K. R.; Jacobs, G.; Graham, U. M.; Davis, B. H.; Mattos, L. V.; Noronha, F. V. Steam and $\mathrm{CO}_{2}$ reforming of ethanol over $\mathrm{Rh} / \mathrm{CeO}_{2}$ catalyst. Appl. Catal., B 2011, 102, 94-109. (19) Sheng, P. Y.; Yee, A.; Bowmaker, G. A.; Idriss, H. $\mathrm{H}_{2}$ Production from Ethanol over $\mathrm{Rh}-\mathrm{Pt} / \mathrm{CeO}_{2}$ Catalysts: The Role of $\mathrm{Rh}$ for the Efficient Dissociation of the Carbon-Carbon Bond. J. Catal. 2002, 208 (2), 393-403.

(20) Sadi, F.; Duprez, D.; Gérard, F.; Miloudi, A. Hydrogen formation in the reaction of steam with $\mathrm{Rh} / \mathrm{CeO}_{2}$ catalysts: A tool for characterising reduced centers of ceria. J. Catal. 2003, 213, 226-234.

(21) Ferencz, Z.; Erdőhelyi, A.; Baán, K.; Oszkó, A.; Óvári, L.; Kónya, Z.; Papp, C.; Steinrück, H. P.; Kiss, J. Effects of support and Rh additive on Co-based catalysts in the ethanol steam reforming reaction. ACS Catal. 2014, 4, 1205-1218.

(22) Varga, E.; Ferencz, Z.; Oszkó, A.; Erdőhelyi, A.; Kiss, J. Oxidation states of active catalitic centers in ethanol steam reforming reaction on ceria based Rh doped Co catalysts: An XPS study. J. Mol. Catal. A: Chem. 2015, 397, 127-133.

(23) Mattos, L. V.; Jacobs, G.; Davis, B. H.; Noronha, F. B. Production of Hydrogen from Ethanol: Review of reaction mechanism and catalyst deactivation. Chem. Rev. 2012, 112, 4094-4123.

(24) Mukainakano, Y.; Li, B.; Kado, S.; Miyazawa, T.; Okumura, K.; Miyao, T.; Naito, S.; Kunimori, K.; Tomishige, K. Surface modification of Ni catalysts with trace $\mathrm{Pd}$ and $\mathrm{Rh}$ for oxidative steam reforming of methane. Appl. Catal., A 2007, 318, 252-264.

(25) Kiennemann, A.; Breault, R; Hindermann, J. P. Ethanol promotion by the addition of cerium to rhodium-silica catalysts. $J$. Chem. Soc., Faraday Trans. 1 1987, 83, 2119-2128.

(26) Zafiris, G. S.; Gorte, R. J. Evidence for a second CO oxidation mechanism on Rh/ceria. J. Catal. 1993, 143, 86-91.

(27) Cordatos, H.; Bunluesin, T.; Stubenrauch, J.; Vohs, M.; Gorte, R. J. Effect of ceria structure on oxygen migration for $\mathrm{Rh} /$ ceria catalysts. J. Phys. Chem. 1996, 100, 785-789.

(28) Overbury, S. H.; Mullins, D. R.; Kundakovic, L. Enhancement of dissociation by metal-support interaction: reaction of $\mathrm{NO}$ on $\mathrm{Rh}$ supported by ceria films of controlled oxidation state. Surf. Sci. 2001, $470,243-254$.

(29) Zhou, J.; Baddorf, A. P.; Mullins, D. R.; Overbury, S. H. Growth and characterization of $\mathrm{Rh}$ and $\mathrm{Pd}$ nanoparticles on oxidized and reduced $\mathrm{CeO}_{x}(111)$ thin films by scanning tunneling microscopy. $J$. Phys. Chem. C 2008, 112, 9336-9345.

(30) Miyazawa, T.; Okumura, K.; Kunimori, K.; Tomishige, K. Promotion of oxidation and reduction of $\mathrm{Rh}$ species by interaction of $\mathrm{Rh}$ and $\mathrm{CeO}_{2}$ over $\mathrm{Rh} / \mathrm{CeO}_{2} / \mathrm{SiO}_{2}$. J. Phys. Chem. C 2008, 112, 25742583.

(31) Trovarelli, A.; Fomasiero, P. Catalysis by Ceria and Related Materials, 2nd ed.; Imperial College Press: London, 2013; p 888.

(32) Campbell, C. T.; Peden, C. H. I. Oxygen vacancies and catalysis on ceria surfaces. Science 2005, 309, 713-714.

(33) Varga, E.; Pusztai, P.; Óvári, L.; Oszkó, A.; Erdőhelyi, A.; Papp, C.; Steinrück, H.-P.; Kónya, Z.; Kiss, J. Probing the interaction of Co, $\mathrm{Rh}$ and $\mathrm{Co}-\mathrm{Rh}$ bimetallic particles with the $\mathrm{CeO}_{2}$ support: catalytic materials for alternative energy generation. Phys. Chem. Chem. Phys. 2015, 17, 27154-27166.

(34) Burroughs, P.; Hamnett, A.; Orchard, A. F.; Thornton, G. Satellite structure in the X-ray photoelectron spectra of some binary and mixed oxides of lanthanum and cerium. J. Chem. Soc., Dalton Trans. 1976, 17, 1686-1698.

(35) Zhang, J.; Yu, X.; Wu, Z. Y.; Liu, T.; Hu, T. D.; Xie, Y. N. Structural characteristics of cerium oxide nanocrystals prepared by the microemulsion method. Chem. Mater. 2001, 13, 4192-4197.

(36) Fouad, N. E.; Mohamed, M. A.; Zaki, M. I.; Knözinger, H. Thermal and spectroscopic studies of feasibility of rhodium acetate versus chloride as a likely precursor for Rh metal catalysts. J. Anal. Appl. Pyrolysis 2000, 53, 185-193.
(37) Munuera, G.; Gonzales-Elipe, A. R.; Espinos, J. P.; Munos, A.; Conesa, J. C.; Soria, J.; Sanz, J. The role of oxygen vacancies during the decomposition of $\mathrm{RhCl}_{3} / \mathrm{TiO}_{2}$ precursor: Study by XPS, IR, EPR and NMR. Catal. Today 1988, 2, 663-673.

(38) Kondarides, D.; Verykios, X. The effect of chlorine on the chemisorptive properties of $\mathrm{Rh} / \mathrm{CeO}_{2}$ catalysts studied byXPS and temperature programmed desorption techniques. J. Catal. 1998, 174, $52-64$.

(39) Pereira, E. B.; Homes, N.; Martí, S.; Fierro, J. L. G. Oxidative steam-reforming of ethanol over $\mathrm{Co} / \mathrm{SiO}_{2}, \mathrm{Co}-\mathrm{Rh} / \mathrm{SiO}_{2}$ and $\mathrm{Co}-\mathrm{Ru} /$ $\mathrm{SiO}_{2}$ catalysts: Catalytic behavior and deactivation/regeneration processes. J. Catal. 2008, 257, 206-214.

(40) van't Blik, H. F. J.; Koningsberger, D. C.; Prins, R. Characterization of supported cobalt and cobalt-rhodium catalysts: III. Temperature programmned Reduction (TPR), oxidation (TPO), ans EXAFS of Co-Rh/SiO 2 . J. Catal. 1986, 97, 210-218.

(41) Ligthart, D. A. J. M.; van Santen, R. A.; Hensen, E. J. M. Influence of particle size on the activity and stability in steam methane reforming of supported Rh nanoparticles. J. Catal. 2011, 280, 206220.

(42) Underwood, R. P.; Bell, A. T. Lanthana-promoted Rh/SiO 2 . J. Catal. 1988, 109, 61-75.

(43) Mo, X.; Gao, J.; Umnajkaseam, N.; Goodwin, J. G. J. La, V, and Fe promotion of $\mathrm{Rh} / \mathrm{SiO}_{2}$ for $\mathrm{CO}$ hydrogenation: Effect on adsorption and reaction. J. Catal. 2009, 267, 167-176.

(44) Solymosi, F.; Pásztor, M. J. Phys. Chem. 1985, 89, 4789-4793.

(45) Van't Blik, H. F. J.; Van Zon, J. B. A. D.; Hulzinga, T.; Vis, J. C.; Koningsberger, D. C.; Prins, R. An extended X-ray absorption fine structure spectroscopy study of a highly dispersed $\mathrm{Rh} / \mathrm{Al}_{2} \mathrm{O}_{3}$ catalyst: The influence of $\mathrm{CO}$ chemisorption on the topology of rhodium. J. Phys. Chem. 1983, 87, 2264-2267.

(46) Bulushev, D. A.; Froment, G. F. A DRIFTS study of the stability and reactivity of adsorbed $\mathrm{CO}$ species on a $\mathrm{Rh} / \mathrm{y}-\mathrm{Al}_{2} \mathrm{O}_{3}$ catalyst with a very low metal content. J. Mol. Catal. A: Chem. 1999, 139, 63-72.

(47) Rice, C. A.; Worley, S. D.; Curtis, C. W.; Guin, J. A.; Tarrer, A. $\mathrm{R}$. The oxidation state of dispersed $\mathrm{Rh}$ on $\mathrm{Al}_{2} \mathrm{O}_{3}$. J. Chem. Phys. 1981, $74,6487-6497$

(48) Stubenrauch, J.; Vohs, J. M. Interaction of $\mathrm{CO}$ with $\mathrm{Rh}$ supported on stoichiometric and reduced $\mathrm{CeO}_{2}(111)$ and $\mathrm{CeO}_{2}(100)$ surfaces. J. Catal. 1996, 159, 50-57.

(49) Ozturk, O.; Park, J. B.; Ma, S.; Ratliff, J. S.; J, Z.; Mullins, D. R.; Chen, D. A. Probing the interactions of $\mathrm{Pt}, \mathrm{Rh}$ and bimetallic Pt-Rh clusters with the $\mathrm{TiO}_{2}(110)$ support. Surf. Sci. 2007, 601, 3099-3113.

(50) Óvári, L.; Kiss, J. Growth of $\mathrm{Rh}$ nanoclusters on $\mathrm{TiO}_{2}(110)$ : XPS and LEIS studies. Appl. Surf. Sci. 2006, 252, 8624-8629.

(51) Sun, H. P.; Pan, X. P. Partial encapsulation of Pd particles by reduced ceria-zirconia. Appl. Phys. Lett. 2005, 87, 201915.

(52) Caballero, A.; Holgado, J. P.; Gonzales-delaCruz, V. M.; Habas, S. E.; Herranz, T.; Salmeron, H. In situ spectroscopic detection of SMSI effect in a $\mathrm{Ni} / \mathrm{CeO}_{2}$ system: hydrogen induced burial and dig out of metallic nickel. Chem. Commun. 2010, 46, 1097-1099.

(53) Bernal, S.; Botana, F. J.; Calvino, J. J.; Cauqui, M. A.; Cifredo, G. A.; Jobacho, A.; Pintado, J. M.; Rodrigues-Isquierdo, J. M. Microstructural and chemical properties of ceria-supported rhodium catalysts reduced at 773 K. J. Phys. Chem. 1993, 97, 4118-4123.

(54) Bernal, S.; Botana, F. J.; Calvino, J. J.; Cifredo, G. A.; PérezOmil, J. A.; Pintado, J. M. HREM study of the behaviour of a $\mathrm{Rh} /$ $\mathrm{CeO}_{2}$ catalyst under high temperature reducing and oxidizing conditions. Catal. Today 1995, 23, 219-250.

(55) Bernal, S.; Calvino, J. J.; Cauqui, M. A.; Cifredo, G. A.; Jobacho, A.; Rodríguez-Izquierdo, J. M. Metal-support interaction phenomena on rhodium/ceria and rhodium/titania catalysts: Comparative study by high-resolution transmission electron spectroscopy. Appl. Catal., A 1993, 99, 1-8.

(56) Radnik, J.; Mohr, C.; Claus, P. On the origin of binding energy shifts of core levels of supported gold nanoparticles and dependence of pretreatment and material synthesis. Phys. Chem. Chem. Phys. 2003, 5, $172-177$. 
(57) Costanzo, E.; Faraci, G.; Pennisi, A. R.; Ravesi, S.; Terrasi, A. Initial and final state effects in photoemission from gold clusters. Solid State Commun. 1992, 81, 155-158.

(58) Gustafson, J.; Westerström, R.; Resta, A.; Mikkelsen, A.; Andersen, J. N.; Balmes, O.; Torrelles, X.; Schmid, M.; P, V.; Hammer, B.; Kresse, G.; Baddeley, C. J.; Lundgren, E. Structure and catalytic reactivity of Rh oxides. Catal. Today 2009, 145, 227-235.

(59) Zhan, R. R.; Vesselli, E.; Baraldi, A.; Lizzit, S.; Comelli, G. The $\mathrm{Rh}$ oxide ultrathin film on $\mathrm{Rh}(110)$ : An $\mathrm{X}$-ray photoelectron diffraction study. J. Chem. Phys. 2010, 133, 214701.

(60) Solymosi, F. Importance of the electric properties of supports in the carrier effect. Catal. Rev.: Sci. Eng. 1968, 1, 233-255.

(61) Sasahara, A.; Pang, C. L.; Onishi, H. Probe microscope observation of platinum atoms deposited on the $\mathrm{TiO}_{2}(110)-(1 \times 1)$ surface. J. Phys. Chem. B 2006, 110, 13453-13457.

(62) Sevcikova, K.; Kolarova, T.; Skala, T.; Tsud, N.; Vaclavu, M.; Lykhach, Y.; Matolin, V.; Nehasil, V. Impact of $\mathrm{Rh}-\mathrm{CeO}_{\mathrm{x}}$ interaction on CO oxidation mechanism. Appl. Surf. Sci. 2015, 332, 747-755.

(63) Cao, Y.; Ran, R.; Wu, X.; Zhao, B.; Wan, J.; Weng, D. Comparative study of ageing conditions effects on $\mathrm{Pd} / \mathrm{Ce}_{0.5} \mathrm{Zr}_{0.5} \mathrm{O}_{2}$ and $\mathrm{Pd} / \mathrm{Al}_{2} \mathrm{O}_{3}$ catalysts: Catalytic activity, palladium nanoparticle structure and Pd-support interaction. Appl. Catal., A 2013, 457, 5261.

(64) Wan, J.; Ran, R.; Wu, X.; Cao, Y.; Li, M.; Weng, D. Redispersion of $\mathrm{Pd}$ on $\mathrm{Ce}_{0.5} \mathrm{Zr}_{0.5} \mathrm{O}_{2}$ upon cooling in the presence of oxygen. Catal. Today 2015, 253, 51-56.

(65) Nagai, Y.; Dohmae, K.; Ikeda, Y.; Takagi, N.; Hara, N.; Tanabe, T.; Guilera, G.; Pascarelli, S.; Newton, M. A.; Takahashi, N.; Shinjoh, H.; Matsumoto, S. In situ observation of platinum sintering on ceriabased oxide for autoexhaust catalysts using Turbo-XAS. Catal. Today 2011, 175, 133-140.

(66) Fu, Q.; Saltsburg, H.; Flytzani-Stephanopoulos, M. Active nonmetallic $\mathrm{Au}$ and $\mathrm{Pt}$ species on ceria-based water-gas shift catalysts. Science 2003, 301, 935-938.

(67) Lin, W.; Herzing, A. A.; Kiely, C. J.; Wachs, I. E. Probing metalsupport interactions under oxidizing and reducing conditions: In situ Raman and infrared spectroscopic and scanning transmission electron microscopic - X-ray energie-dispersive spectroscopic investigation of supported platinum catalysts. J. Phys. Chem. C 2008, 112, 5942-5951.

(68) Hosokawa, S.; Taniguchi, M.; Utani, K.; Kanai, H.; Imamura, S. Affinity order among noble metals and $\mathrm{CeO}_{2}$. Appl. Catal., A 2005, 289, 115-120.

(69) Dictor, R.; Roberts, S. Influence of ceria on alumina-supported rhodium; observations of rhodium morphology made using FTIR spectroscopy. J. Phys. Chem. 1989, 93, 5846-5850.

(70) Wang, Z.; Yang, F.; Axnanda, S.; Liu, C.; Goodman, D. W. Preparation and characterization of $\mathrm{Co}-\mathrm{Rh}$ bimetallic model catalysts: From thin films to dispersed clusters. Appl. Catal., A 2011, 391, 342349.

(71) Tanaka, H.; Kaino, R.; Okumura, K.; Kizuka, T.; Nakagawa, Y.; Tomoshige, $\mathrm{K}$. Comparative study of $\mathrm{Rh} / \mathrm{MgO}$ with $\mathrm{Fe}$, Co or $\mathrm{Ni}$ for the catalytic partial oxydation of methane at sort contact time. Part I. Characterization of catalysts. Appl. Catal., A 2010, 378, 175-186.

(72) Naito, S.; Tanaka, H.; Kado, S.; Toshihiro, M.; Naito, S.; Okumura, K.; Kunimori, K.; Tomoshige, K. Promoting effect of Co addition on the catalytic partial oxydation of methane at short contact time over a $\mathrm{Rh} / \mathrm{MgO}$ catalyst. J. Catal. 2008, 259, 138-146.

(73) Li, D.; Sakai, S.; Nakagawa, Y.; Tomoshige, K. FTIR study of $\mathrm{CO}$ adsorption on $\mathrm{Rh} / \mathrm{MgO}$ modified with $\mathrm{Co}, \mathrm{Ni}, \mathrm{Fe}$ or $\mathrm{CeO}_{2}$ for the catalytic partial oxidation of methane. Phys. Chem. Chem. Phys. 2012, 14, 9204-9213.

(74) Kim, Y. D.; Stultz, J.; Wei, T.; Goodman, D. W. Interaction of $\mathrm{Ag}$ with $\mathrm{MgO}(110)$. J. Phys. Chem. B 2002, 106, 6827-6830.

(75) Zhang, C.; Michaelides, A.; King, D. A.; Jankins, S. J. Anchoring sites for initial $\mathrm{Au}$ nucleation in $\mathrm{CeO}_{2}\{111\}$ : $\mathrm{O}$ vacancy versus $\mathrm{Ce}$ vacancy. J. Phys. Chem. C 2009, 113, 6411-6417.

(76) Sanchez, M. G.; Gazquez, J. L. Oxygen vacancy model in strong metal-support interaction. J. Catal. 1987, 104, 120-135.
(77) Pusztai, P.; Puskás, R.; Varga, E.; Erdőhelyi, A.; Kukovecz, Á.; Kónya, Z.; Kiss, J. The effect of gold additives on the stability and phase transformation of titanate nanostructures. Phys. Chem. Chem. Phys. 2014, 16, 26786-26797.

(78) Lu, Z.; Yang, Z.; Hermansson, K.; Castleton, C. W. M. Several different charge transfer and $\mathrm{Ce}^{3+}$ localization scenarios for $\mathrm{Rh}$ $\mathrm{CeO}_{2}(111)$. J. Mater. Chem. A 2014, 2, 2333-2345.

(79) Murgida, G. E.; Ganduglia-Pirovano, M. V. Evidence for subsurface ordering of oxigen vacancies on the reduced $\mathrm{CeO}_{2}(111)$ subsurface using density-functional ans statistical calculations. Phys. Rev. Lett. 2013, 110, 246101.

(80) Kullgren, J.; Hermannsson, K.; Broqvist, P. Supercharged lowtemperature oxygen storage capacity od ceria at the nanoscale. J. Phys. Chem. Lett. 2013, 4, 604-608.

(81) Renuka, N. K.; Harsha, N.; Divya, T. Supercharged ceria quantum dots with exceptionally high oxygen buffer action. RSC Adv. 2015, 5, 38837-38841.

(82) Xu, J.; Harmer, J.; Li, G.; Chapman, T.; Collier, P.; Longworth, S.; Tsang, S. C. Size dependent oxygen buffering capacity of ceria nanocrystals. Chem. Commun. 2010, 46, 1887-1889.

(83) Verma, R.; Samdarshi, S. K.; Bojja, S.; Paul, S.; Choudhury, B. A novel thermocatalyst of mixed-phase cerium oxide $\left(\mathrm{CeO}_{2} / \mathrm{Ce}_{2} \mathrm{O}_{3}\right)$ homocomposite nanostructure: Role of interface and oxygen vacancies. Sol. Energy Mater. Sol. Cells 2015, 141, 414-422.

(84) Aslam, M.; Oamar, M. T.; Soomro, M. T.; Ismail, I. M. I.; Salah, N.; Almeelbi, T.; Gondal, M. A.; Hameed, A. The effect of sunlight induced surface defects on the photocatalytic activity of nanosized $\mathrm{CeO}_{2}$ for the degradation of phenol its derivatives. Appl. Catal., B 2016, 180, 391-402.

(85) Wang, K.; Chang, Y.; Lv, L.; Long, Y. Effect of annealing temperature on oxygen vacancy concentrations of nanocrystalline $\mathrm{CeO}_{2}$ film. Appl. Surf. Sci. 2015, 351, 164-168.

(86) Pereira, A.; Blouin, B.; Pillonnet, A.; Guay, D. Structure and valence properties of ceria films synthetized by laser ablation under reducing atmosphere. Mater. Res. Express 2014, 1, 015704.

(87) Fierro, J. L. G.; Palacios, J. M.; Tomas, F. An analitycal SEM and XPS study of platinum-rhodium gauzes used in high pressure ammonia burners. Surf. Interface Anal. 1988, 13, 25-32.

(88) Blomberg, S.; Lundgren, E.; Westerström, R.; Erdogan, E.; Martin, N. M.; Mikkelsen, A.; Andersen, J. N.; Mittendorfer, F.; Gustafson, J. Structure of the $\mathrm{Rh}_{2} \mathrm{O}_{3}(0001)$ surface. Surf. Sci. 2012, 606, 1416-1421.

(89) Vayssilov, G. N.; Lykhach, Y.; Migani, A.; Staudt, T.; Petrova, G. P.; Tsud, N.; Skála, T.; Bruix, F.; Illas, F.; Prince, K. C.; Matolin, V.; Neyman, K. M.; Libuda, J. Support nanostructure boosts oxygen transfer to catalytically active platinum nanoparticles. Nat. Mater. 2011, 10, 310-315.

(90) Bruix, A.; Rodriguez, J. A.; Ramirez, P. J.; Senanayake, S. D.; Evans, J.; Park, J. B.; Stacchiola, D.; Liu, P.; Hrbek, J.; Illas, F. A new type of strong metal-support interaction and the production of $\mathrm{H}_{2}$ through the transformation of water on $\mathrm{Pt} / \mathrm{CeO}_{2}(111)$ and $\mathrm{Pt} / \mathrm{CeO}_{\mathrm{x}} /$ $\mathrm{TiO}_{2}$ (110) catalysts. J. Am. Chem. Soc. 2012, 134, 8968-8974.

(91) Nefedov, V. I.; Firsov, M. N.; Shaplygin, I. S. Electronic structures of $\mathrm{MRhO}_{2}, \mathrm{MRh}_{2} \mathrm{O}_{4}, \mathrm{RhMO}_{4}$ and $\mathrm{Rh}_{2} \mathrm{MO}_{6}$ on the basis of $\mathrm{X}$-ray spectroscopy and ESCA data. J. Electron Spectrosc. Relat. Phenom. 1982, 26, 65-78.

(92) Tolia, A. A.; Smiley, R. J.; Delgass, W. N.; Takoudis, C. G.; Weaker, M. J. Surface oxidation of rhodium at ambient pressures as probed by surface-enhanced Raman and X-ray photoelectron spectroscopies. J. Catal. 1994, 150, 56-70.

(93) Nörenberg, H.; Briggs, G. A. D. Defect formaton on $\mathrm{CeO}_{2}(111)$ surfaces after annealing studied by STM. Surf. Sci. 1999, 424, L352L355.

(94) Norman, A.; Perrichon, V.; Bensaddik, A.; Lemaux, S.; Bitter, H.; Koningsberger, D. Study of the reducibility of Pt or Pd on ceriazirconia catalysts by XANES measured at the $\mathrm{Ce} \mathrm{L}_{\mathrm{III}}$ edge and magnetic susceptibility measurements. Top. Catal. 2001, 16, 363-368. 
(95) Divins, N. J.; Llorca, J. In situ photoelectron spectroscopy study of ethanol steam reforming over $\mathrm{RhPd}$ nanoparticles and $\mathrm{RhPd} / \mathrm{CeO}_{2}$. Appl. Catal., A 2015, DOI: 10.1016/j.apcata.2015.08.018.

(96) Yang, Z.; Luo, G.; Lu, Z.; Woo, T. K.; Hermansson, K. Structural and electronic properties of NM-doped ceria $(\mathrm{NM}=\mathrm{Pt}$, Rh): a first-principle study. J. Phys.: Condens. Matter 2008, 20, 035210. 